\title{
DEMOCRATIC TRANSITIONS: ARE THERE RECIPES FOR SUCCESS?
}

\author{
Deina Abdelkader*
}

\begin{abstract}
In transitioning to democracy, rationalists assume that either the masses or the elites bring about change. This paper hypothesises that there is a causal relationship between the actors involved in social change and the end product-the progress of democratic transition and whether revolution from below or from above is more likely to bring about the transition. By examining Pacting Theory as a democratic transition theory, this paper will analyse the role of the military in Egypt's democratisation process. The interplay of the military powers and relinquishing those powers to a civilian government will have implications for social movements theory and the approaches to democratic transition theory.
\end{abstract}

Keywords: Democratic Transition, Comparative Democratisation, Thick Approaches, Thin Approaches, Military Powers, Pacting Theory, Social Movement Theory.

\section{Introduction}

The rational choice theory has explained democratic transition majorly through two forces in society: the first force is the elite and the second is through mass mobilisation. In the first case, elite-centred explanations of democratic transition (DT) assume that divisions within the elites are causal to DT. In the second case, mass-mobilisation is causal to DT.

My paper will majorly focus on the case of Egypt and the Arab Spring, i.e. I will discuss democratic transition theories, domestic, and international variables, by utilising what happened in Egypt since January of 2011 till our contemporary time.

If we look at the actors involved in the 25 January [2011] movement, we will find that the revolution succeeded in overthrowing an authoritarian ruler due to a combination of mass protests and divisions within the elite groups, e.g. the ruling family and the military.

At face value, it seems that in the case of Egypt, the masses were the instigators of change to attempt DT. 
Before delving into more analysis on the Egyptian attempt at DT, a clarification of the state of comparative democratisation is essential.

This paper intends to use what Coppedge has termed "thick theory": "Thick approaches lend themselves to a rich understanding of specific events; thin approaches lend themselves to hypothesis testing and generalisation." He further clarifies:

I argue that existing quantitative indicators are adequate for some purposes but that we cannot measure democracy much better until we thicken the concept that we are operationalising to take multiple dimensions of democracy into account. ${ }^{1}$

Coppedge also stressed the contestations surrounding the definition of democracy and what democratic transition entails:

Unfortunately, one of the most difficult challenges in studying democratisation has been reaching agreement on what "democracy" is. In fact, W.B. Gallie once argued that democracy is one of the best examples of an essentially contested concept. ${ }^{2}$

When qualitative and quantitative analysts say "democracy", they literally mean different things. Strictly speaking, research on the causes of thin democracy, speak only to the research on thin democratisation; research on the causes of thick democracy has relevance for a longer and richer theoretical tradition. ${ }^{3}$

One of the data sets that exemplify thin theory is the Arab Barometer data. This data is based on a paper by Beissinger, Jamal, and Mazur entitled "Who Participated in the Arab Spring? A Comparison of Egyptian and Tunisian Revolutions." The paper explained how they "measured" piety in Tunisia and Egypt as follows:

"To capture levels of piety, we constructed a fifteen-point scale measuring the frequency with which individuals perform five behaviours associated with religiosity, including reading the Quran or Bible and praying."

This approach, however, risks inaccuracies in its evaluation. Questions regarding people's practice of the faith is culturally and politically loaded, thus 
highly sensitive. Even the illiterate would be wary of responding to such questions. This weariness is derived from the colonial and post-colonial experience that entails apologetic behaviour on the part of indigenous peoples. Without getting into further historical detail (which is exactly what Coppedge thinks is of prime significance), it is obvious that the questions in the survey were culturally and historically inappropriate. The research also contradicted itself by stating that:

Though we have no direct evidence on the religious character of civil society associations, it is reasonable to infer that many were religious in orientation; Islamic charitable societies and religious movements like the Muslim Brotherhood in Egypt and Ennahda in Tunisia exemplify this tendency. ${ }^{5}$

The above statement suggested that they were fully aware that gathering information about religious practices did not provide them with direct evidence on the religious character of civil society.

The cited paper also indicates that according to their survey, participants in the revolution in Egypt demonstrated "primarily about the economy, with demands for civil and political freedoms ranking relatively low." ${ }^{\prime 6}$ How does this data and research reconcile the fact that Wael Ghonim ${ }^{7}$ was deemed as the symbol of the revolution because of his Facebook page titled: "We are all Khaled Saeed," referring to a young student who was brutally attacked in public by the police till he died, then the government forced forensics to say that he died because of a drug overdose, a year before the revolution.

Another example of the study contradicting its own findings is the statement:

participants in the Egyptian Revolution were disproportionately middleaged, middle class, professional, and religious. ${ }^{8}$

Later on, the study stated:

Similarly, religiosity does not appear to be systemically related to protest participation. ${ }^{9}$

Again a few pages later the authors state:

Though we have no direct evidence on the religious character of civil society associations, it is reasonable to infer that many were religious in orientation; Islamic charitable societies and religious movements like 
the Muslim Brotherhood in Egypt and Ennahda in Tunisia exemplify this tendency. ${ }^{10}$

The paper's attempt at defining who the participants were in the Egyptian revolution, however, did detect some important facts: The data reflects on the participants' social classes and whether they belonged to civil society associations, and those questions are easier to answer in a survey, then the questions referred to earlier concerning piety and faith. The methods used in collecting the data and their analysis largely also depend on a theoretical map of the field, and this is where the focus of the paper will shift to the theoretical component of mass mobilisation, revolution, and democratic transition.

\section{Comparative Democratisation Theory and the Causes of Democratic Transition}

Democratisation is a largely contested term as indicated previously. However, there are a few overarching causal variables that affect democratisation. A succinct summary of those factors is:

1. Economic progress is directly correlated to sustaining democratisation

2. Elites are essential participants in the process of democratisation

3. Elites are essential participants in maintaining/sustaining democratic transitions.

4. Parliamentary systems supersede presidential systems in most countries transitioning towards consolidating democratic practices

5. Lack of border disputes and inclusiveness of all minorities is necessary for democratisation to take place and to be sustainable.

6. A strong state with institutions and public servants acting in public interest are an essential component to democratisation. ${ }^{11}$

\section{Comparative Democratisation in Search of a Theoretical Agenda}

First, a major detractor from forming a common theoretical agenda for democratisation is the fact that:

Methodological specialisation has encouraged conceptual and theoretical divergence, and that divergence has eased our balkanisation into different methodological camps. 
(This) Comes at the cost of a common language and a cumulative research agenda. It is in the best interest of the social sciences to resist these trends by encouraging multimethod research that leads to a more holistic understanding of democratisation. ${ }^{12}$

Second, Robert Dahl's polyarchy has limited the convergence of theorists utilising "procedural democracy" from other theorists who work with "participatory democracy", i.e. the theorists who are more focused on the informal non-institutional forms of democratic expression. e.g. analysing the role of civil society in bringing about or affecting democratic transition..$^{13}$

Third, engaging in more case studies and comparative histories because those studies create a theory and allow for rigorous testing.

Fourth, and more specifically in analysing Egypt's transition to democratisation, it is important to note that:

The political history of Africa, Asia, and the Middle East is comparatively under-theorised. ${ }^{14}$ Expanding into non-Western regions is one way this approach could capitalise on its strengths. ${ }^{15}$

Building on Bunce's broad definition of factors affecting democratic transition, there are two factors that have played a considerable role in the Egyptian revolution:

The first is the participation of the middle class; the second is the effect of civil society on the revolution. According to the comparative study cited earlier, the authors have stressed that according to their data, ${ }^{16}$ participants in Tunisia and Egypt had: "above average levels of income and education and were disproportionately from professional or clerical occupational backgrounds." 17 In this comparison, however, the authors have significantly erred in a number of ways:

1. As mentioned earlier in constructing any survey questionnaire, the rudiments of cultural and social respect are necessary. Generically speaking this question is extremely private and specifically intolerable in Islam because "piety" is a relationship between God and the worshipper; there is no hierarchy, there are no intermediaries. Therefore it is either that the responders had answered incorrectly or that the sample was not representative. Also, as discussed earlier, it is a loaded question due to cultural and historical sensitivity.

2. The authors mentioned that 'absolute deprivation was not a major factor' in the uprisings, but the spark that led to the revolution in Tunisia came 
from a fruit seller, so how do we reconcile this fact? Also, even if we go along with the assumption that "absolute deprivation" did not play a role, what about "relative deprivation" theory: the authors do not mention it although it coincides with the majority of their findings.

The study then affirms through its findings that 55 percent of the participants in the Egyptian revolution were from the middle-class background, this statement agrees with Joel Beinin's study. ${ }^{18}$

However, again, the Arab Barometer study overgeneralises when it states that: "In both revolutions participants largely understood participation as being primarily about the economy, with demands for civil and political freedoms ranking relatively low." ${ }^{19}$ In reality, the spark for the revolution was a web page created by a Google employee that decried abuse and brutality by the police. Therefore, the collected data is not in agreement with plain facts that the revolutionaries themselves voiced and believed in.

The comparative study on the whole presented two pieces of information that are valuable and could be utilised as building blocks for defining the nature of those social movements, which also determines the direction the countries will take in terms of democratic transition.

First, the study's stress on the socio-economic class of the revolutionaries, mainly the middle class, as opposed to the assumption that those revolutions took place because of poverty or below poverty line grievances. This finding indicates that the aspirations for igniting the revolution were based on human and civil rights goals such as egalitarianism, justice, dignity, and democratisation.

Second, the study's stress on the role of civil society associations in igniting the revolution particularly in Egypt is in agreement with other theoretical studies. ${ }^{20}$ Thus, in effect, the semi-authoritarian state produced the seeds that later blossomed into the 25 January revolution. ${ }^{21}$ According to Ottaway, she defines semi-authoritarianism as basically the political posturing of an authoritarian regime that attempts to appear "liberaldemocratic" without really risking the political status quo. Ottaway, however, underestimates the political space (and even limited power) that is gained by civil society organisations with the regime's mere flirting with such liberties (i.e. even semi-authoritarian regimes could, in fact, allow the development of political groups/ organisations that challenge the status quo).

Complex causality is strongly demonstrated by another factor that thin theory does not capture: that in Egypt and other Arab countries: "social movements have "very limited resources and weak formal organisations. 
They typically rely on informal networks and innovative repertoires to mobilize," ${ }^{22}$ an example of that is 6 April movement members actions before the revolution: they pretended to call on their cell-phones and conveyed the message of when, where, and how, the revolution was to take place, on metro lines, in taxicabs...etc.

\section{Social Movements in the Middle East: Current Criticisms of Regional Studies in the Area of Social Movements}

Given that social movements and civil society organisations are oppressed and restricted with varying degrees in the region and that they lack major political openings, it is particularly interesting in the field to observe and analyse how those societies operate through those restricted spaces to aspire and demonstrate for political rights.

First, this paper is in total disagreement with "cultural exceptionalism" as an explanation of social mobilisation in the Arab Spring, in general, or in the Muslim world more broadly. That is to say, this paper takes a middle range approach, which takes the context as a central factor in understanding how informal networks in the Middle East and North Africa operate and how actors among them calculate when they do so. The implication that Japan and the Middle East and North Africa may share comparable forms of local networking does not mean that there is an essential East/West divide on this or other matters. Rather we suggest that the West may not be as rational and instrumentalist as many have imagined it to be. ${ }^{23}$

Second, theoretically, most modelling in comparative politics and political science as a whole is built on the global North and therefore southern regions become the outliers in what is assumed to be the norm politically. What this comparative paper studies and emphasises is that regional cases also could contribute to the classical questions of social mobilisation and democratic transition theory i.e. the Global South also needs to be included in our studies of all things political theoretically. Contemporary politics are full of examples that currently prove that the universality of certain political concepts is challenged every day. It is time then to be inclusive of those experiences to enrich our thin theories and recognise that comparative politics or Democratic transition theories are not unilaterally defined.

Third, and last, it is important to note a problem that Beinin and Variel clearly state: "categories like "nation", "class," and even "Islam" have no "objective" existence or trans-historical essence, They are inherently problematic and should always be disaggregated, localised, and contextualised." ${ }^{24}$ Generalisation then, 
or grand theory becomes hazardous in capturing highly contested definitions such as "Islam", "democracy", "modernity" and etc.

\section{One Step Forward and Two Step Back: The Case of the Egyptian Revolution}

In the wake of Tunisia's success in getting rid of Zine El-Abidine Ben Ali, Egyptian activists began to keep in touch with Tunisia's activists to learn from their success in getting rid of Zein el Abidin Bin Ali via social media. The spark of the revolution quickly travelled to Egypt, given its long history of injustices, the activist's goal was to merely reform police practices on 25 January 2011 (which is also Police day in Egypt). The activists and many youths had gathered in each other's houses and were connected via social media whereby the killing of one of the youth in Alexandria sparked a long discussion about police brutality. The young man was called Khaled Saeed; he posted a video of policemen dividing drugs amongst themselves after capturing them. The police thugs surrounded an Internet café that Khaled was in, and they beat him to death in front of bystanders. The youth then started organising themselves more adamantly because they empathised with Khaled and thought they could be next in line with this total lack of a legal system, human rights violations, and blatant police brutality.

The revolt on 25 January was a revolt against police brutality, but the spark of the revolution caught on and the longer it took the incumbent regime to respond to the people's demands, the higher the demands were increased and the more the people became more intolerant of the whole regime.

Finally, the resignation of Mubarak came on 11 February and the players on the political scene changed: a military council was formed allegedly to protect the revolutionaries, but as discovered through hindsight, the military was, in fact, protecting its own domestic and international interests. The military gets the lion's share of US aid to Egypt, and therefore to maintain their disproportionate share of Egypt's economy their move was tactical and in total disregard and disconnect from the revolution, as well as its causes and goals.

Police brutality, pitting the Coptic minority as a cause for state interference, torture, virginity tests for women: all came back after 11 February when Mubarak was ousted. Since then the highlights of the military's success in killing the revolution and intimidating any opposition to its interests, are as follows: an American trained and close acquaintance of Mubarak's regime, General Sisi ordered the arrest and trial of elected President Morsi. The show of support for Sisi's move is highly controversial because the military knew that impressing the idea that the people called for ousting the elected President was necessary 
to legitimise their actions and to continue to receive aid from the United States. Since 30 June 2013, when the military coup took place, the crowds staged a sitin protest in a square called Rab'aa because the military did not allow them to stage protests in Tahrir anymore. Tahrir Square became synonymous with stagein celebrations for pro-Sisi supporters. After issuing a warning for the protestors to go home and leave Rab'aa, the military and the police (including police thugs) rampaged the crowds in what was the bloodiest attack on any political group in Modern Egyptian history on 14 August 2013. The number of casualties ranged from 1,000-2,000, and the wounded were double those numbers. Group burials of many of the casualties were common after burning the bodies to prevent their kins' upheaval. The military then through the media and the legal system demonised the Muslim Brotherhood and in the name of fighting "terrorism" continued to torture, abuse, and silence any opposition to its rule. They created a constitution through an unelected group of people and later rigged a referendum approving the constitution by 95 percent.

More detailed accounts are available on Human Rights Watch and Amnesty International.

\section{The Military's Role in Democratic Transition: The Case of Egypt}

The military is one of the oldest and strongest institutions in the political arena, yet it is forgotten in many ways as the pivotal cause for change from above by most of the literature especially in democratic transition literature, which is this paper's focus. ${ }^{25}$

According to Robert Springborg: "Explaining the variation in the responses of militaries to the outbreak of protest, therefore, is vital to understanding the overall course of the Arab uprisings. ${ }^{26}$ It is also important to note that with the little attention paid to the institution, and the fact that the institution itself "burrowed" with different degrees in the Arab world, it also became highly secretive to the detriment of researchers trying to gain accurate information about the military. ${ }^{27}$ According to Barany: "One of the main reasons why recent Middle Eastern and North African events took so many observers by surprise was the sheer opacity of these countries especially their military establishments, to outsiders." ${ }^{28}$

As an institution, the military in Egypt has exhibited power and economic existentialism. The military as a political player is also involved in regional politics as well as politics with the United States. It is important to address each one of those issues to establish the connections needed to prove or disprove this paper's hypothesis. 


\section{A. Power}

The relationship between the Egyptian army and its people is an intriguing one because although the army was repeatedly defeated over the years, images of gallantry and nationalism have consistently played a role in the Egyptian psyche. The army had control over all tools of propaganda to claim victory in each war that they lost, by controlling the media, the arts, and most importantly education. Although the defeat of 1967 was announced and Abdel Nasser offered to resign as the head of state, nevertheless in the 1970s and specifically after the 1973 war, the army started regaining its inflated ego as an institution. The Egyptian army had initially won the 1973 war because of the element of surprise that they employed, however, soon enough the Israeli military had regained its ability to respond to the attacks, and a ceasefire was established to end further hostilities. As of 1979 when the Egyptian-Israeli peace treaty was signed, the Egyptian army has become an institution that is extremely hierarchical but also reliant, especially the upper echelons, on Western luxury goods. By signing the Peace treaty in 1979, the Egyptian army became a docile, highly consumerist institution, and

as adequately capture by Sayigh, Egypt became the "Officer's Republic." 29 The army since their coup in 1952 and till current times have been protective not to establish serious civilian institutions that could play a prominent political role, as Marina Ottaway indicates, during Mubarak's time, the regime was a "semiauthoritarian" regime that allowed for a multiparty system, and a relatively free media, however, if any of those parties or media sources threatened the status quo, they were severely dealt with. As observed in a lot of the writing about the Egyptian revolution, the army' hold on power was so relentless, that even Mubarak had to establish a strong police force in his attempt to hand over power to his civilian son Gamal Mubarak. Although Mubarak was part of the military, but his attempt to hand over power to a civilian existentially threatened the military's power and therefore they: "on 10 February, the Supreme Council of the Armed Forces (SCAF) assumed control of the country and, the next day, persuaded a reluctant Mubarak to resign and head for internal exile." 30

The military also supported a candidate in the country's first free election in 2012, but their candidate lost to the Muslim Brotherhoods candidate: a civilian, bringing the political tension to an all-time high when the military finally stepped in in $2013 .{ }^{31}$

\section{B. Economy}

The second lynchpin or causal factor that affects the existential conflict and raison d'etre that the Egyptian military has is its economic interests. As recognised by Barany, the military's economic involvement is: 
In everything from housewares and military gear production to farming and tourism. The revenue from these enterprises goes straight to the military's coffers and is disbursed without state oversight. We can sense the importance of these business endeavours by noting that Field Marshal Mohamed Hussein Tantawi, who chaired the SCAF and heads the Defense Ministry, also runs the Ministry of Military Production. Military officers directly profit from the army's business endeavours through relatively high salaries plus preferential treatment in medical care, housing, and transport. And, of course, the armed forces also reap US $\$ 1.3$ billion every year in military aid from the United States. ${ }^{32}$

In agreement, Czulda writes:

The Egyptian military has forged an industrial empire over decades and become one of the biggest employers in a relatively poor country. It has dozens of factories and companies, which produce almost everything: from olive, milk, bottled water, clothes to televisions and cars. The Egyptian military own sports grounds, restaurants, farms, resorts, and hotels. $^{33}$

Not only did the revolution threaten the economic status quo, but it also affected the tourism industry, which is also controlled by the military. ${ }^{34}$

The military's economic involvement is so entrenched that:

There is no political force that could stop them. Since 2011 the armed forces have increasingly taken on the biggest infrastructure projects. As Joshua Stacher put it, "we're dealing with a brand-new economy that's now run by Military Inc." 35

\section{The Egyptian Military and Relations with the State of Israel}

The shared borders between Egypt and Israel have continuously played a role in detecting diplomatic signalling of how peaceful versus aggressive the regime is towards Israel. Thus, after the signature of the Camp David peace agreement, the Egyptian borders became a buffer zone, not unlike the Syrian Golan Heights. Maintaining this buffer zone requires the Egyptian military to suppress and control, with an iron fist, its own Sinai Bedouin population. ${ }^{36}$ Not only does the Egyptian military need to repress its own population, but also it needs to tighten control over its borders by closing the Rafah entrance points to the Palestinian Gazan population. ${ }^{37}$ 
As Czulda notes: "The Arab Spring, and especially the election of M. Morsi, was greeted in Israel with great anxiety - more as a threat than as an opportunity. Despite the new president's close ties to Hamas, Prime Minister Benyamin Netanyahu sent a message of congratulation and expressed hope that bilateral relations would remain cooperative although expecting problems. However, the impact of the Arab Spring on Egypt-Israel relations very soon became visible. Bilateral communication at the operational level, mainly through security and intelligence channels, stopped." 38

In support of Israeli fears on the changes in the status-quo along its Egyptian borders:

In March 2012, the Egyptian parliament, already dominated by the Muslim Brotherhood, called for the cutting of ties with Israel, including stopping exporting gas, as well as "re-examining" the Camp David peace accords of 1978 between "revolutionary Egypt" and the "Zionist regime." 39

Upon the military's return to power:

Egypt banned Hamas (now considered an enemy) from operating inside the country, shifted of the Rafah border crossing, destroyed all known tunnels going from Egypt to the Gaza Strip and demolished homes along the border, to establish a planned buffer zone to prevent smuggling. This was a very conscious, but at the same time very provocative and hostile act by A.F el-Sisi. ${ }^{40}$

\section{U.S.-Egyptian Military Relations}

The United States involvement in Egyptian politics harkens back to the 1950s during the cold war, when financing the Aswan Dam was rejected, and Abdel Nasser turned to the Soviet Union for support. After the death of Abdel Nasser, Sadat turned 180 degrees and decided to become a United States ally in 1970. After the 1973 war with Israel and regaining his population's respect and regional allegiance, Sadat decided single-handedly to enter into negotiations with Israel in which the United States played the role of peace broker, and a new chapter of U.S.-Egyptian relations was created with the signing of the peace agreement. Since then, U.S.-Egyptian politics have become intertwined:

In March 2014, General Lloyd J. Austin III (Commander of U.S. Central Command) called Egypt an 'anchor state'. In other words - Egypt is too important to let go, no matter what happens inside it. The best proof of 
this statement is in the numbers: in 2012 more than 2,000 U.S. military aircraft flew in Egyptian airspace. Up to 45 U.S. $5^{\text {th }}$ Fleet naval ships pass through the Suez Canal annually. Cutting aid would push Egypt into the hands of anti-Western groups, and neither the United States nor Israel can afford that. ${ }^{41}$

When the revolution took place, the United States was hesitant to withdraw support from Mubarak, and although the crackdown on the revolutionaries was brutal, bloody and internationally televised, it took the United States and Europe a while before they timidly supported the revolutionaries, i.e. it was out of international embarrassment and not due to real-politique calculations that the United States succumbed to the interests of a whole nation. The United States, however, did not support the revolution wholeheartedly because as soon as Morsi came into power in 2012 by popular vote for the first time in Egyptian history, and was kidnapped by a coalition of the military and the old regime, the United States tried to convince itself and the world that imprisoning Morsi at the hands of his own military was not a coup: "this is not the first time that the United States chose Realpolitik instead of human rights and liberal values."

Arms sales and financial aid continue today without interference, although it is no secret that the regime has caused an unsurpassed amount of bloodshed and incredible human rights conditions. ${ }^{43}$

In hindsight, the United States' position never changed because:

Although the Arab world received a disproportionate amount of U.S. funding to promote democracy, it received virtually no support to enhance civilian control of the militaries. The one study of Arab civilmilitary relations financed before the Arab spring by the United States Agency for International Development (USAID) noted the politically important role of Arab militaries and their absorption of record shares of public budgets but questioned "the ripeness of many countries in the region for major programs in civil-military relations." ${ }^{\prime 4}$

\section{E. Causal Factors of the Egyptian Military's Reaction to Democratic Transition}

First, the military in Egypt, as in many Middle Eastern countries, has total control of power. Power sharing by civilian institutions or a balance of power between the military and civilian institutions is unheard of. This balance has come about in other transitions especially in Latin America through the United States' interference: 
The United States Department of Defense's Center for Civil-Military Relations has played a vital role in raising political consciousness and providing necessary information for effective civilian control of the armed forces. ${ }^{45}$

Second, the military is highly suspicious of civilian involvement in the economy, and their expertise does not go beyond domestic production and sales of goods and services, however, what is needed for an economy to survive is to be able to navigate the global economy: an issue that the army has failed at miserably:

The economy is in poor condition, and the military has no idea how to change that. What is more, they see no reason to change it significantly, as they profit from the current situation. Social peace in Egypt requires more jobs and higher salaries, but this is impossible without more freedom and liberalism. ${ }^{46}$

Third, demographically speaking, the youths who ignited the revolution and who have been silenced and imprisoned by the military regime are increasing in number. This demographic increase will affect the political scene in Egypt in the very near future.

On a more general and theoretical note, Pacting as a theory of political transition is not inclusive of international factors that could affect the transition and therefore lacks the ability to explain the failure of the Arab "Spring" in the Middle East region.

As Blumberg adequately states, specialists of the Middle East region are facing a "paradigm crisis;" transition theories and post-transition theories have: "A striking incapacity to theorise the role of local cultures, political logics, or ideologies in either regime change or stasis." 47

He argues: "What we need instead is a more 'bounded' approach, one that looks at how political change, contestation, and negotiation in the Arab world are conditioned by local, national, or regional forces. Among these forces, the role of identity conflicts is a crucial variable, one that merits more serious conceptualisation within a broader (if midrange) theory of change." ${ }^{98}$

\section{Contemporary Egypt and Antagonistic ${ }^{49}$ "Liberalism": Old Wine in New Bottles}

Although western liberalism is partially built on the acceptance and respect of others, the observance of pluralism, and the protection of both, "liberalism" in 
Egypt pre and post the 2011 revolution antagonistically rejects and refuses to co-exist with what it views as its main rival: Islamically oriented politics and parties. Quintessential liberalism is defined by the rejection of a privileged class, religion, or national origin...etc., however "liberals" in Egypt have basically argued and acted on their assumption that they are the "privileged" holders of the truth politically, socially and economically.

Historically speaking the "liberals" in Egypt have copied Orientalist criticisms of the "Occident" and assumed that they are scientific truths with a capital T..$^{50}$ What distinguishes those "secular-liberalists" is that they "uncritically replicated European anti-Arabism and the debasement of the Arabo-Islamic culture." 51

That is to say that, the "liberals" emphasised the same critiques of the Other (the "Orientalist"). They identified with the culture of the Other to the demise of their own culture. They touted those critiques as "scientific truths." Their "liberalism" was non-inclusive of the masses, which is still true today in the aftermath of the 2011 Egyptian revolution:

The secular liberal reformers, who emphasised rationality and individualism, were paradoxically trapped in the cultural order of the Other and therefore could not provide an inclusive notion of national identity and an emancipating notion of political community. ${ }^{52}$

In the 1920s and 1930s, the "liberals" of Egypt adopted the discourse of the "Orientalist" wholeheartedly so much so that their writings included: "overt racial and cultural discrimination." ${ }^{53}$ In evaluating the public discourse after the revolution, especially with the ascendance of Dr Morsi to power, this 'liberal' biases can be primarily observed in the social media; whether in the form of jokes on Facebook about how he and his wife look, or whether one refers to the dry humour of Dr Bassem Yousef who became an icon of free speech under Dr Morsi.

The language that was used was so derogatory that a television talk show host came outright on public television and addressed it on her show. Although the talk show host had opposing political views, she defended Mrs Morsi and said that one could critique her ideas if she speaks, but it is unfair to attack her based on her looks or her modest appearance, she said she looks like most middle-class women and that aiming those jokes at Mrs Morsi was a classic case of snobbery and classism. ${ }^{54}$ 


\section{Religious Public Discourse and Public Policy}

Since the presidency of General Sisi, there has been a crackdown on the public display of religiosity including religious institutions and mosques:

Two months ago, worshippers at Al-Rahman, a small mosque in the Ain Shams district in eastern Cairo, turned up for prayers on Friday, the Muslim day of rest, to find the doors shut. From now on, they were told, they would have to go to one of the city's main mosques for the most important prayers of the week. Soon after, another restriction was added when a group that met for discussions about Islam was told to stop. Today the mosque is open for weekday prayer only. ${ }^{55}$

Human rights groups see a good reason for all to be worried by the new restriction. This in effect kills the idea of religious freedom since Egyptians can't opt for any religious practice not approved by the authorities..$^{56}$

Thus, public policy towards the Islamic faith has been threatening since the advent of the new political regime in Egypt. Not only do people have restrictions in praying where they want, but also religious practice is controlled and monopolised by al-Azhar, which in turn is controlled by the regime.

More recently the speech given by Mr Sisi is also imbued with threats. In his speech, he indicated that the faith needs reform. Sisi's message created waves of discontent and fear:

The religious discourse that should be idolised is one that is relevant to our time, to renew the faith every 100 years. I am talking here to the people of religion and the people who are responsible for this faith: It is impossible that the ideas that we adhere to our ideas that promote disturbance in the world, worry and killing. I do not mean the faith, but the ideas that are idolised for hundreds of years. Discarding those ideas have become very difficult, to the extent that those ideas are the enemy of the whole world. Is it possible for 1.6 billion to kill 7 billion? It's impossible! I am saying this at al-Azhar, in front of the scholars of religion. I hold you responsible on the day of judgment about what I just said. It is impossible to feel the faith while one is enshrined in it; you have to (exit) the faith to judge it, and for one to be enlightened. You need to stop, we need a religious revolution. (5 January 2015) 
Again, although opposition or commentary on Mr Sisi's speech is nonexistent, commentaries on social media express their fear and frustration. The perception of Mr Sisi's speech is that policy-wise there will be more restrictions on the public practice and public discourse about Islam. For him to refer to a religious revolution and to talk about renewal is reminiscent of the missionary, and colonial discourse referred to previously. His call is also contradictory in spirit because Mr Sisi keeps repeating, "I do not mean the faith", and meanwhile he is de facto addressing the religious scholars. Mr Sisi also repeats several times that those scholars are responsible: how could he hold them responsible for what happened in Paris for example? Is he using the same discourse that is being used by Western countries to shame the 1.6 billion Muslims for the actions of three or four Muslims?

Mr Sisi's implied assumption that the 1.6 billion Muslims are out to fight the 7 billion is also indicative of Western Islamophobia because his speech has a lot more in common with people gathered at Dresden a few weeks ago to request the ousting of Muslims from Germany, than with the majority of Muslims who are against violence. His call for renewing the faith and revolutionising it was hailed by Western and Israeli media sources, but to his Muslim audience, it sounded threatening and repulsive. Recent historical facts and research show that when the public will to practice its faith is under attack, the followers of the faith become more radicalised. More importantly, as illustrated, the leader of Egypt is repeating the age-old colonial and Islamophobic arguments. His public discourse is accusatory of the whole faith and all of its followers: "Is it possible for 1.6 billion to kill 7 billion It's impossible!"

Adding salt to injury, Mr Sisi's speech transgresses identity politics in a country that is well renowned for its faith. Sisi's speech exemplifies the age-old problem with liberalism, basically taking on the Other's argument and adopting it as one's own, without adaptation or allowing public space for the masses and what they want.

\section{Conclusion}

In conclusion, I would like to highlight two points:

First, theoretically the field is going through an identity crisis:

1. Comparative politics, as well as comparative democratisation, is being forcefully pigeonholed to build a grand theory which by definition is opposed to cultural and historical nuances.

2. Also, analysts are not linking the domestic level of analysis to the 
international, for example, post-Arab Spring, Egyptian politics were affected by the political stronghold of the military as well as the foreign policy interests of the United States and its regional ally Israel.

3. The negligible amount of literature on the agency of political actors in the Arab Spring which is linked to a bias in the literature that I address in my research, namely, the divide between rational versus irrational, secular versus religious.

Second, the arguments used by the "liberals" in the 20s and 30s have not changed in Egypt post-January 2011. The same tactics and opinions are held. The distance between the "liberals" and the masses is quite vast. The revolt ('coup') carried out by the military supporters was replicated in many countries especially in Turkey's modern history.

The Egyptian liberals held that in a culturally 'backwards' society, the masses do not have the capacity to make meaningful choices, and therefore the exclusion of their voices needs no theoretical justification or political explanation. The kind of social and cultural "emancipation" they preached is grounded in a self-evident cultural justification of political subordination. The masses became the object of an arbitrary and authoritative discourse telling them how to dress, how to eat, what to read, what to believe, how to cross the street, how to choose a conjugal partner, how to celebrate a birth, and how to mourn and bury the dead. In short, they were expected to renounce their cultural identities and moral values and assume an alien, 'superior' political identity, Except for the simplistic and phoney racial theories on the inferiority of Arab culture and the superiority of Western civilization, the Egyptian reformers did not bother to offer the public compelling reasons to give up parts of their cultural identity in order to enjoy citizenship rights. ${ }^{57}$

It is this disconnect between the few and the masses that brought about the current political climate in Egypt. Democratic practice is founded on "the people" when political actions and speeches go against the public will and ethos, the regime loses legitimacy and ceases to be democratic.

The "liberals" in the 1920s and 1930s were shocked to see the reluctance of the masses in adopting their ways:

"The masses cannot adjust to the historic changes the country is undergoing." Complained the liberal reformers. Because of their inability to adjust, their allegiance to the new Egyptian nation could not 
be guaranteed. The masses were considered "abnormal", "socially ill," and in urgent need of containment, surveillance, and medical treatment. Egyptian society was viewed as a mixture of pathological groups to be treated, literally, by medical experts to "normalise" their integration as abstract individual citizens into the newly defined political community. ${ }^{58}$

Those realisations noted by Maghraoui have continued to haunt Egyptian politics and act as constraints on the public will, but they have come even further pronounced as a result of $25^{\text {th }}$ January revolution and the resultant free election of the Muslim Brotherhood.

Oddly enough the liberals ignited the $25^{\text {th }}$ January revolution; the Muslim Brotherhood was in a constant state of opposition before the revolution, however, when the public gave birth to a different political view, the "liberals" rushed to erase those choices.

The political-social divide has been addressed by popular media: A wellknown pop-singer (Ali el-Haggar) released a song titled: 'They are a people, and we are a people'. The song vilifies the Muslim Brotherhood as 'terrorists' and glorifies the 'proper' citizens. As al-Effendi writes in an article published recently:

There is indeed, a belief that the elite belongs to a superior race and that the rest of the Egyptian people are up for slaughter as they increase in number. There is not a problem, therefore, if they are killed wholesale. There are still debates about the numbers of those who have been killed. Is it four thousand in total or one and a half thousand? In the end, it does not really matter.

The conflict in Egypt is not simply a matter of disagreements between secularists and Islamists or between liberals and conservatives it is a dispute between Egypt's ordinary people, those who are rooted in its soil, and the elite who have been determining the way of things since the time of Muhammad Ali and his successors. These elites are the people who have hijacked the state and monopolised the nation's wealth for use as a weapon against the people so that they may know their "place". 59

In conclusion, it is very dangerous to obliterate one side of the population, especially the majority from political participation and discourse. Social movement theories indicate that change can occur from above or from below. If one does a comparative study of the region, Egypt, in particular, has been 
historically resistant to change from above. Whether one takes Qasim Amin, Huda Shaarawi as feminists, or Nasserism as a national-socialist experiment, neither feminism from above nor socialist Nasserism gained traction as ideas that mobilised the masses.

In examining the history of the Muslim Brotherhood as a social movement, they, on the other hand, gained traction as a movement, and their ideas were popularised because they addressed the real needs of the people: free healthcare, free education, transportation...etc. Not only did the Brotherhood act as a state within a state providing those services, but also their reluctance to adopt Western liberalism wholesale brought their ideas and convictions closer to the people. The great divide between upper class-liberal versus masses-religious is replicated in Turkey and Iran's modern history: whether we talk about Nejm Eddin Erbakan and his struggles, as a precursor to Erdogan, or Iran pre and post the 1979 Iranian revolution are both proofs that change from above and trying to shove "secularism" down the throat of a religious population does not work. At the end of the day, people hide their religious convictions until the system allows them to express those convictions freely.

The underscoring of social justice lies at the heart of this great divide because as this paper has illustrated, the divide between the elites-interest groups and the masses is complex. This divide is also based on the kind of education they received, the historical context of this education (i.e. power relations), and above all the ripples of colonisation are still felt till this day in the region.

\section{Policy Recommendations}

- The experience of Egypt, Turkey and Iran shows that a top-down strategy to impose secularism on religious people is bound to fail, and on the other hand, a religiously inspired movement from the grass-roots which addresses everyday problems of the common people is likely to be successful. Therefore, in similar contexts, any social movement and democratic struggle should be bottom-up.

- The theorisation of democratic transition and comparative politics should be enriched with a deeper analysis of local analysis and local political actors to address the biased divide in the literature between the rational and irrational and religious and secular. 


\section{Notes}

* Deina Abdelkader, Ph.D, is a Comparitivist and International Relations specialist. Her scholarly interests focus on the Middle East and North Africa, Comparative Democratisation in the Muslim World, Islamic Activism, and the Role of Muslim Women in Religious Interpretation. She is the author of Social Justice in Islam and Islamic Activists: The Anti-Enlightenment Democrats.

1. Michael Coppedge, Democratization and Research Methods (Cambridge: Cambridge University Press, 2012), 6.

2. Ibid., 11.

3. Ibid., 23.

4. Beissinger Mark. R. Amaney Jamal and Kevin Mazur, 'Who Participated in the Arab Spring? A Comparison of Egyptian and Tunisian Revolutions,' Annual convention of the American Political Science Association, 13. Available at: http://www.princeton.edu/ mbeissin/beissinger.tunisiaegyptcoalitions.pdf (Accessed on: 12 January 2015).

5. Ibid., 16.

6. Ibid., 20-1.

7. A political activist who also worked for Google as a computer engineer.

8. Beissinger, Jamal, and Mazur, 'Who Participated in the Arab Spring?', 4.

9. Ibid., 13.

10. Ibid., 16.

11. Bunce, Valerie, 'Comparative Democratization: Big and Bounded Generalizations,' Comparative Political Studies Journal 33, no. 6-7 (2000): 706-15.

12. Coppedge, Democratization and Research Methods, 310-1.

13. Ibid., David Held, Models of Democracy, $3^{\text {rd }}$ ed.(Stanford: Standford University Press, 2006).

14. Michelle Pace, The Politics of Regional Identity: Meddling with the Mediterranean (Oxford: Routledge,2005); Jason Brownlee, Authoritarianism in an Age of Democratization (Cambridge: Cambridge University Press, 2007); Hui VTB, War and State Formation in Ancient China and Early Modern Europe (Cambridge: Cambridge University Press, 2005); Dan Slater, Ordering Power: Contentious Politics and Authoritarian Leviathans in Southeast Asia (Cambridge: Cambridge University Press, 2010).

15. Coppedge, Democratization and Research Methods, 316.

16. The Arab Barometer Survey Data.

17. Beissinger, Jamal, and Mazur, 'Who Participated in the Arab Spring?', 12

18. Joel Beinin, Frédéric Vairel, Social Movements, Mobilization, and Contestation in the Middle East and North Africa (Palo Alto: Stanford University Press, 2013).

19. Beissinger, Jamal, and Mazur, 'Who Participated in the Arab Spring?', 20-1

20. Marina Ottaway "Facing the Challenge of Semi-Authoritarian States," The Chronicle of Higher Education, 7 February, 2003. Republished in Annual Editions: Comparative Politics 2008-2009 by Christian Soe, 28-31.

21. There has been a great deal of hesitance to call the "Arab Spring" movements' 
revolutions or uprisings. This paper will use the terms interchangeably. Most literature is wary of calling them revolutions because mostly all the countries/ movements did not realise change in the political system. As opposed to this rationalist bias, of not achieving their goals, this paper asserts that change in political perceptions, breaking the fear barrier and knowing what the people's rights are, is central to actually calling it a revolution.

22. Beinin, Social Movements, Mobilization, and Contestation, 6-7.

23. Ibid., 11.

24. Ibid., 8 .

25. Robert Springborg writes: "The decisions by Arab militaries played a crucial role in determining the outcomes of their countries' protest movements. In some cases, such as Egypt and Tunisia, military leaders decided to refrain from using their violent power to crush protestors and instead to jettison the regime's leadership... political science literature is poorly equipped to address this pivotal question" Marc Lynch, The Arab Uprisings Explained: New Contentious Politics in the Middle East (New York: Columbia University Press, 2014), 142.

26. Ibid.

27. Ibid., 142-3.

28. Zoltan Barany, 'The role of the Military', Journal of Democracy vol. 22, no. 4 (2011): 164.

29. Yezid, Sayigh, 'Above the State: The Officers' Republic in Egypt, The Carnegie Papers,' Carnegie Endowment for International Peace. Available at: http:// carnegieendowment.org/files/officers_republic1.pdf (Accessed on: 28 October 2014).

30. Barany, 'The role of the Military', 166.

31. "M. Morsi, who failed to secure full control over the military, was overthrown in July 2013". Robert Czulda, 'The Impact of the Arab Spring on the Military Security Policy of Egypt,' in Transformation Processes in Egypt after 2011: The Causes, Their Course and International Response, ed. Fiedler, R., Osiewicz, P., \& Logos Verlag Berlin GmbH (Berlin: Logos Berlin, 2015), 78.

32. Barany, 'The role of the Military', Journal of Democracy Volume, 166.

33. Czulda, 'The Impact of the Arab Spring on the Military Security Policy of Egypt,' 76.

34. Ibid., 78 .

35. Ibid.

36. The Bedouin population was bombed and re-located after general Sisi came to power in 2013.

37. The Gazan population is caught in a pincer pinch because Israel has built a wall to separate them and Egypt has also cut them off by tightening border control. Therefore, Gazans are cut off from trade, economic survival, medical help... etc. It is the most militarised segment of the Palestinian population under Hamas leadership because of their living conditions. In the meantime, Israel bombs the Gazan population as a whole with no discrimination and no international accountability in sight.

38. Czulda, 'The Impact of the Arab Spring on the Military Security Policy of Egypt,' 79.

39. Ibid., 80 . 
40. Ibid., 80-1.

41. Ibid., 83 .

42. Ibid.

43. Reuters: 11 February 2016.

44. Lynch, The Arab Uprisings Explained, 143.

45. Ibid., 153.

46. Czulda, 'The Impact of the Arab Spring on the Military Security Policy of Egypt,' 88.

47. Lynch, The Arab Uprisings Explained, 31.

48. Ibid., 30.

49. The antagonistic quality that is added to "liberalism" here expresses the inimical and oppositional stance liberals took against an ideological and socio-economic opponent; namely the Muslim Brotherhood. The antagonistic quality is also in reference to the disrespect and belittling of the majority of the masses ideas and beliefs. As former Vice President, Umar Suleiman said in a CNN interview in 2011: "The Egyptians do not understand democracy", which oddly enough echo British colonial views of Egypt during its occupation.

50. Maghraoui lists those liberals:

"This group included literary figures such as Taha Husayn, Muhammad Husayn Haykal, Abbas Mahmud al-Aqqad, and Tawfiq al-Hakim; social critics such as Fathi Zaghlul and Isma'il Mazhar; Christian Arab emigres, mainly publishers, such as Salama Musa, Farah Antoun, Jurji Zaydan, and Shibli Shumayal; and political leaders such as Ahmad Lutfi al-Sayyid, publicly known as Ustadh alJil, the master thinker of his generation."

51. Maghraoui, Liberalism without Democracy: Nationhood and Citizenship in Egypt, 67.

52. Ibid., 68.

53. Ibid., 85-6.

54. Reem Majed, 2/7/2012, Masrawy.com

55. Islam in Egypt, 'Manipulating The Minarets: The Government Wants To Control The Mosques,' The Economist. Available at: https://www.economist. com/middle-east-and-africa/2014/08/02/manipulating-the-minarets (Accessed on: 2 February 2015).

56. Ibid.

57. Maghraoui, Liberalism without Democracy, 88.

58. Ibid., 90.

59. Memo Middle East Monitor, 'The Killing of an Activist Masks the Real Conflict in Egypt,' Middle East Monitor. Available at: https://www.middleeastmonitor. com/20150202-the-killing-of-an-activist-masks-the-real-conflict-in-egypt/ (Accessed on: 5 October 2015). 